\title{
LIMIT CASES: HOW AND WHY WE CAN AND SHOULD DECRIMINALISE HIV TRANSMISSION, EXPOSURE, AND NON-DISCLOSURE
}

\author{
Matthew Weait
}

\begin{abstract}
Across the world, people living with HIV and AIDS (PLHA) face investigation, prosecution, conviction, and punishment if they transmit HIV to another person, expose others to the risk of HIV acquisition, or fail to disclose in advance their HIV positive status. This article seeks to explain why limiting the criminalisation of HIV is important and necessary; identifies some of the ways in which it has been, and might be, limited; and, finally, offers some reflections on whether there exists a principled limit to decriminalisation arguments (i.e. whether there are cases which, even if the general principles underpinning decriminalisation is accepted, justify state punishment). Drawing on recent international policy guidance, current scientific knowledge about HIV prevention and treatment, research on the impact of criminalisation of PLHA, the article argues that decriminalisation is critical to eradicating HIV and should be a public health priority, that biomedical advances in prevention and treatment will assist the decriminalisation project but are insufficient in the absence of legal and criminal justice practice reform.
\end{abstract}

\section{KEYWORDS}

Criminalisation, Criminal Law, HIV, Law Reform, Public Health

\section{INTRODUCTION}

Across the world, people living with HIV and AIDS (PLHA) face investigation, prosecution, conviction, and punishment if they transmit HIV to another person, expose others to the risk of HIV acquisition, or fail to disclose in advance their HIV positive status. ${ }^{1}$ This article seeks to explain why limiting the criminalisation of HIV is important and necessary; identifies some of the ways in which it can be limited; and, finally, offers some reflections on whether there exists a principled limit to decriminalisation arguments (i.e. whether there are cases which, even if the general principles underpinning decriminalisation is accepted, justify state punishment). Drawing on recent international policy guidance, current scientific knowledge about HIV prevention and treatment, research on the impact of criminalisation of PLHA, it argues that decriminalisation is critical to eradicating HIV and should be a public health priority, that biomedical advances in prevention and treatment will assist the decriminalisation project but are insufficient in the absence of legal and criminal justice practice reform.

\section{LEGAL PRINCIPLES AND ARGUMENTS AGAINST HIV CRIMINALISATION}

The criminalisation of HIV operates at the intersection of law, science, and human behaviour. Doctrinally, the legal principles are not particularly complex. Although criminalisation provisions

\footnotetext{
${ }^{1}$ The Global Network of People Living with HIV, The Global Criminalisation Scan Report, Documenting Trends Presenting Evidence (2010) Amsterdam: GNP+<https://www.gnpplus.net/2010-global-criminalisation-scanreport/> (accessed 30 July 2018); M Weait, The Criminalisation of HIV Exposure and Transmission: A Global Review. Working Paper prepared for the Third Meeting of the Technical Advisory Group, Global Commission on HIV and the Law, 7-9 July, 2011; Global Commission on HIV and the Law, Risks, Rights \& Health (2012) and Supplement (2018) UNDP: New York < https://hivlawcommission.org> (accessed 30 July 2018)
} 
differ between jurisdictions ${ }^{2}$, the basic position is that HIV is typically treated as a (serious) bodily harm. This means that a person living with HIV who is proven to have caused another person to become infected (transmission liability), or to have exposed another person to the risk of infection (exposure, or in some cases attempt, liability), is, provided she acts with the requisite fault and in the absence of a recognised defence, guilty of an offence. In some jurisdictions the failure to disclose HIV positive status prior to engaging in activity which carries with it the risk of onward transmission vitiates any consent to that activity and renders it criminal (thus, in Canada, non-disclosure of status may convert otherwise consensual sexual intercourse into an aggravated sexual assault ${ }^{3}$ ). As far as fault provisions are concerned, these too depend on the specific jurisdiction, but insofar as it is possible to generalise, transmission, exposure, and non-disclosure are criminalised where a person knows that they have an HIV positive diagnosis and acts intentionally or recklessly with respect to these behaviours. ${ }^{4}$ An allegation of attempt to infect will generally require proof that there was a deliberate, purposeful, desire to infect (and is distinguishable from exposure liability, where recklessness will usually suffice). In some jurisdictions, such as England and Wales, the consent of a partner to the risk of acquisition provides a full defence where HIV is transmitted recklessly. ${ }^{5}$

On the face of it, there are sound reasons to criminalise those who culpably infect, or who are ostensibly willing to risk infecting, others with HIV. They centre on the harmful impact of the disease on individuals and populations, and the need to deter risk-taking taking behaviour in the interests of public health. However, legal scholars, clinicians, virologists, and epidemiologists, along with civil society and international organisations, have long advocated against what they see as the unjust and ineffective use of the criminal law. Although there is widespread consensus among anticriminalisation advocates that while the most egregious and morally blameworthy conduct (deliberately, purposefully, infecting another person with HIV - in effect using the virus as a weapon) may legitimately be criminalised, this is the only justifiable circumstance. ${ }^{6}$ The reasons why all other cases do not justify the use of the criminal law have been articulated clearly and in detail elsewhere ${ }^{7}$, but in essence the central concerns may be summarised as follows.

First, there is scant evidence that criminalisation is effective on public health grounds (as a general or individual deterrent against practising unsafe sex), and some growing evidence that it is ineffective and counter-productive. A recent comprehensive review of empirical research on the impact of HIV exposure laws in the US, for example, concluded:

Study results also suggest that the laws do not deter HIV testing among persons at risk for HIV infection, or decrease or increase serostatus disclosure to sex partners among

\footnotetext{
${ }^{2}$ Some jurisdictions have HIV-specific criminalisation provisions, while others (including the UK), use their general criminal laws relating to offences against the person. See Risks, Rights, \& Health (2012 Report and 2018 Supplement, note 1 ).

${ }^{3}$ This is the case where there is a 'realistic possibility of transmission': $R$ v Mabior (2012) SCC 47. See I Grant, The over-criminalisation of persons with HIV' (2013) University of Toronto LJ 63(3) 475

${ }^{4}$ Intention and recklessness are terms of legal art. Intention may be established by proving a desire to bring about the proscribed consequence or, in some cases, inferred where the consequence was virtually certain to arise, and the defendant was aware that it was virtually certain. For a person to be found reckless this will typically mean establishing that, at the relevant time, she was consciously aware of taking an unjustifiable risk. See Weait, M Intimacy and Responsibility: the Criminalisation of HIV Transmission (2007) Abingdon: Routledge. ${ }^{5} R$ v Dica [2004] EWCA Crim 1103; $R$ v Konzani [2005] EWCA Crim 706. See further, M Weait, 'Criminal Law and the Sexual Transmission of HIV: $R \vee$ Dica' (2005) The Modern Law Review 68 121; M Weait 'Knowledge, autonomy and consent: $R v$ Konzani' (2005) Criminal Law Review 763

${ }^{6}$ Global Commission on HIV and the Law, Risks, Rights \& Health (2012) and Supplement (2018) UNDP: New York < https://hivlawcommission.org> (Accessed 30 July 2018)

${ }^{7} \mathrm{R}$ Jürgens, J Cohen, E Cameron, et al 'Ten reasons to oppose the criminalization of HIV exposure or transmission' (2009) Reproductive Health Matters 17(34) 163
} 
PLH [sic]. The laws also do not appear to reduce sexual risk behaviors among HIVpositive or -negative persons. Records of arrests and prosecutions reveal that many cases involve non-sexual behaviors or sexual activities that pose little to no risk of HIV transmission. ${ }^{8}$

It is important to note that the incarceration of those on remand for or convicted of transmission and exposure offences further exacerbates the epidemic, given the prevalence of sexual activity, injecting drug use, and the limited harm reduction facilities (such as condoms, syringe exchange programmes, etc) that are typically available in detention settings. ${ }^{9}$ Furthermore, a significant proportion of new HIV infections result from sexual activity between those who were previously negative and those who are positive but undiagnosed (and therefore not on treatment and potentially more infectious). ${ }^{10}$ Because criminal liability generally only applies to those who know their positive status, and can therefore be held morally responsible, it is incapable of being an effective prevention tool against transmission in this context. (Conversely although there is relatively little empirical evidence to suggest that people are dissuaded from testing as a result of criminalisation ${ }^{11}$, there is the possibility that people may assume that PLHA will necessarily disclose their status or insist on safer sex (in order to avoid liability), when this may not be the case, thus creating a false sense of security.)

Second, overly broad criminalisation reproduces and reinforces negative stereotypes about PLHA through (frequently inaccurate and sensationalist) press coverage of trials and convictions. ${ }^{12}$ This contributes to the stigma associated with HIV, which in turn creates obstacles to prevention and treatment ${ }^{13}$ and undermines the right of PLHA to the highest attainable standard of physical and mental health and wellbeing ${ }^{14}$. Sexual health physicians, nurses, and advisers may feel conflicted -

\footnotetext{
${ }^{8}$ D Harsono, CL Galletly, E O’Keefe, Z Lazzarini ‘Criminalization of HIV Exposure: A Review of Empirical Studies in the United States' (2017) AIDS and Behavior 21(1) 27; see also, for example, K Horvath, C Meyer, and BRS Rosser, 'Men who have Sex with Men who Believe that their State has a HIV Criminal Law Report Higher Condomless Anal Sex than those who are Unsure of the Law in their State' (2017) AIDS Behav 21(1) 58

${ }^{9}$ R Jürgens, M Nowak, M Day 'HIV and Incarceration: Prisons and Detention' (2011) Journal of the International AIDS Society 14 26; SJA Lindbom, M Larsson, A Agardh 'The naked truth about HIV and risk taking in Swedish prisons: A qualitative study' (2017) PLoS ONE 12(7): e0182237; P Valera, Y Chang, Z Lian 'HIV risk inside U.S. prisons: a systematic review of risk reduction interventions conducted in U.S. prisons' (2017) AIDS Care 29(8) 943

10 J Skarbinski, E Rosenberg, G Paz-Bailey, et al 'Human Immunodeficiency Virus Transmission at Each Step of the Care Continuum in the United States' (2015) JAMA Intern Med 175(4) 588; RT Gray, DP Wilson, RJ Guy et al 'Undiagnosed HIV infections among gay and bisexual men increasingly contribute to new infections in Australia' (2018) Journal of the International AIDS Society 21(4) e25104

${ }^{11}$ SG Lee 'Criminal law and HIV testing: empirical analysis of how at-risk individuals respond to the law' (2014) Yale J Health Policy Law Ethics 14(1) 194. This quantitative US study found that people at risk of acquiring HIV living in states with HIV-specific statutes were "no less likely to report having been tested for HIV than those who live in other states" but that the number of people reporting having been tested for HIV was "inversely correlated with the frequency of newspaper coverage of criminalization of HIV-exposing behavior"

12 P O'Byrne, J Willmore, A Bryan, et al 'Nondisclosure prosecutions and population health outcomes: examining HIV testing, HIV diagnoses, and the attitudes of men who have sex with men following nondisclosure prosecution media releases in Ottawa, Canada' (2013) BMC Public Health 13 94; JM Kilty and K Bogosavljevic 'Emotional storytelling: Sensational media and the creation of the HIV sexual predator' (2018) Crime, Media, Culture 10.1177/1741659018773813

13 UNAIDS HIV-Related Stigma, Discrimination and Human Rights Violations, UNAIDS Best Practice Collection (2005) Geneva: UNAIDS; S Chaudoir and JD Fisher 'Stigma and the "Social Epidemic" of HIV: Understanding BiDirectional Mechansims of Risk and Resilience' Chapter 25 in B Major, JF Dovidio, BG Link (eds) (2018) The Oxford Handbook of Stigma, Discrimination, and Health, Oxford: OUP

${ }^{14}$ World Health Assembly, 'Avoidance of Discrimination against HIV-infected Persons and Persons with AIDS' Adopted at its $41^{\text {st }}$ Meeting on 13 May 1988 (Resolution 41.24)
} 
to the detriment of their patients, their own professional identity, and public health more generally - if they feel obliged to raise the question of criminalisation with those have been diagnosed positive, and there is the risk that the relationship of trust critical to patient care is compromised. ${ }^{15}$

Third, there are countless examples of cases in which the criminal law has been used, even where the defendant took reasonable precautions and there was no transmission ${ }^{16}$, or where there was no risk of infection ${ }^{17}$, to impose extremely harsh sanctions; and cases where police, prosecutors, lawyers, and courts have failed to understand the scientific evidence adduced to support allegations of, and convictions for, transmission. ${ }^{18}$ There is, in addition, evidence that criminalisation disproportionately impacts women ${ }^{19}$, people from minority ethnic communities and those from socially marginalised groups ${ }^{20}$, and is discriminatory in its application.

It should be apparent that there is not only an increasingly strong evidence base that the criminalisation of HIV transmission, exposure, and non-disclosure has a detrimental impact on efforts to prevent the spread of the disease, but also that there are persuasive reasons for decriminalisation grounded in fairness and social justice considerations. The next section considers some of the ways in which the use of the criminal law might be limited, and examples of where it has been, identifying some of the advantages and disadvantages of each. Particular attention will be paid to the potential impact of recent Clinical Consensus Statements, which seek to inform criminal justice and judicial decision makers about the risks associated with various kinds of activity that might result in onward HIV transmission.

\section{LIMITING CRIMINALISATION: STRATEGIES AND TECHNIQUES}

$<$ http://apps.who.int/iris/bitstream/handle/10665/164201/WHA41_A-Conf.Papers-

2_eng.pdf?sequence $=1 \&$ isAllowed $=y,>$ (Accessed 3 August 2018); UNAIDS/OCHCR International Guidelines on HIV/AIDS and Human Rights (1998/2006)

<http://www.unaids.org/en/resources/documents/2006/20061023_jc1252-internguidelines_en.pdf>

(Accessed 3 August 2018)

${ }^{15} \mathrm{C}$ Dodds, M Weait, A Bourne, and S Egede 'Keeping confidence: HIV and the criminal law from HIV service providers' perspectives', (2015) Critical Public Health, 25(4) 410; E Mykhalovskiy 'The problem of "significant risk": Exploring the public health impact of criminalizing HIV non-disclosure' (2011) Social Science \& Medicine 73(5) 668; SE Patterson, M-J Milloy, G Ogilvie, et al 'The impact of criminalization of HIV non-disclosure on the healthcare engagement of women living with HIV in Canada: a comprehensive review of the evidence' (2015) Journal of the International AIDS Society 18(1) 20572; C Sanders 'Discussing the Limits of Confidentiality: The Impact of Criminalizing HIV Nondisclosure on Public Health Nurses' Counseling Practices' (2014) Public Health Ethics 7(3) 253; M French 'Counselling anomie: clashing governmentalities of HIV criminalisation and prevention' (2015) Critical Public Health 25(4) 427

${ }^{16}$ See, for example, Rhoades v lowa Supreme Court of lowa June 13 2014, Case No. 12-0180. Rhoades was sentenced to 25 years imprisonment, and served time in custody, but appealed successfully.

${ }^{17} \mathrm{G}$ Kovatch 'Prison for Man with H.I.V. Who Spit on a Police Officer' May 16 2008, New York Times <https://www.nytimes.com/2008/05/16/us/16spit.html?ref=health> (Accessed 3 August 2018). Willie Campbell, the man who spat, was sentenced to 35 years imprisonment.

${ }^{18}$ AB Abecasis, AM Geretti, J Albert, L Power, M Weait and AM Vandamme 'Science in court: the myth of HIV fingerprinting' (2011) Lancet Infect Dis, 11(2) 78;

${ }^{19}$ The Athena Network 10 Reasons Why Criminalization of HIV Transmission or Exposure Harms Women (2009) <http://www.athenanetwork.org/assets/files/10\%20Reasons\%20Why\%20Criminalization\%20Harms\%20Wom en/10\%20Reasons\%20Why\%20Criminalisation\%20Harms\%20Women.pdf> (Accessed 3 August 2018)

${ }^{20}$ A Hasenbush, A Miyashata, BDM Wilson, The Williams Institute, UCLA School of Law, HIV Criminalization in California: Penal Implications for People Living With HIV/AIDS (2015)

$<$ http://williamsinstitute.law.ucla.edu/wp-content/uploads/HIV-Criminalization-California-Updated-June2016.pdf> (Accessed 3 August 2018) 
The decriminalisation of HIV has been pursued in a number of different ways and through a variety of channels over the past three decades or so. Reflecting a distinctive dimension of the politics of HIV and AIDS ${ }^{21}$, it has been a campaign characterised by a shifting alliance of grassroots activists, civil society and supranational intergovernmental organisations, dedicated campaign groups, legal academics and practitioners, social and political scientists, politicians and policy makers, public health and HIV physicians, clinicians, virologists, and epidemiologists. Each of these has brought their particular expertise, experience, concerns, authority, and voice, creating a loose but sustained coalition that has been effective not only in raising awareness about the problems with, and consequences of, criminalisation but in achieving a number of significant victories using a variety of different techniques. These efforts might be grouped together, without any implied priority, in the following way. (It should also be noted that the people involved in these activities and organisations have multiple identities, and may, for example, be academics living with HIV, or clinician activists.)

Supranationally there has been a number of high-level interventions, taking the form of evidenceand rights-based recommendations to states. These include, most notably, policy and legal guidance, and reports, from UNAIDS, UNHCR, and the Special Rapporteur on the Right to Health ${ }^{22}$, and the Report of the Global Commission on HIV and the Law ${ }^{23}$. Such interventions have typically been based on evidence gathered in consultations and dialogues with affected communities, experts, and civil society representatives, and on published academic research. Their intention is to inform and influence governments and legislatures, often providing examples of best practice, with clear explanations of the socio-economic benefits of legal reform and disbenefits of failing to act. Complementing these interventions are those of international NGOs, such as the International Planned Parenthood Federation ${ }^{24}$, along with those which are national, jurisdiction-focused, and ones that seek to provide specific guidance to audiences with a particular responsibilities and roles in criminalisation policy and practice. Some of the most notable national examples are those of the Canadian HIV/AIDS Legal Network ${ }^{25}$, the US Center for HIV Law \& Policy ${ }^{26}$, and the UK's National

\footnotetext{
${ }^{21}$ C Patton Sex and germs: the politics of AIDS (1985) Boston: South End; S Epstein, Impure science: AIDS, activism, and the politics of knowledge (1996) Berkeley: University of California Press; D Altman and K Buse 'Thinking politically about HIV: political analysis and action in response to AIDS' (2012) Contemporary Politics 18(2) 127; R Parker, 'Grassroots activism, civil society mobilisation and the politics of the global HIV/AIDS epidemic' (2011) Brown Journal of World Affairs, 17(2) 21; NA Paxton, 'Political science(s) and HIV: a critical analysis' (2012) Contemporary Politics, 18 (2) 141

22 UNAIDS Criminal Law, Public health and HIV Transmission: A Policy Options Paper (2002) Geneva: UNAIDS UNCHR HIV/AIDS and Human Rights: International Guidelines (1998) New York and Geneva: United Nations UNAIDS Policy Brief: Criminalization of HIV transmission (2008) Geneva: UNAIDS; UNAIDS Guidance Note: Ending overly broad criminalization of HIV non-disclosure, exposure and transmission: critical scientific, medical and legal considerations (2013) Geneva: UNAIDS

<http://www.unaids.org/sites/default/files/media_asset/20130530_Guidance_Ending_Criminalisation_0.pdf> (Accessed 3 August 2018)

UN Human Rights Council, Report of the Special Rapporteur on the right of everyone to the enjoyment of the highest attainable standard of physical and mental health, 27 April 2010, A/HRC/14/20

<http://www.refworld.org/docid/4c076fb72.html> (Accessed 9 August 2018)

${ }^{23}$ Global Commission on HIV and the Law, Risks, Rights \& Health (2012) and Supplement (2018) UNDP: New

York < https://hivlawcommission.org> (accessed 30 July 2018)

24 IPPF Verdict on a Virus: Public Health, Human Rights and Criminal Law (2008) London: IPPF

<https://www.ippf.org/sites/default/files/verdict_on_a_virus.pdf>. This was produced with the International Community of Women Living with HIV (ICW) and GNP+, and was the basis for the Criminalize Hate, Not HIV campaign <https://www.ippf.org/resource/criminalize-hate-not-hiv> (Accessed 8 August 2018)

25 <http://www.aidslaw.ca/site/?lang=en>

26 < http://www.hivlawandpolicy.org>
} 
AIDS Trust ${ }^{27}$, and of the targeted type guidance that has addressed police ${ }^{28}$, prosecutors ${ }^{29}$, parliamentarians $\mathrm{s}^{30}$, and the judiciary ${ }^{31}$.

A second form of decriminalisation advocacy has been that undertaken by grassroots activist networks, projects, and campaigns. Part of a long established and effective tradition in the politics of HIV and AIDS (such as the Treatment Action Campaign in South Africa ${ }^{32}$ and ACT UP in the US ${ }^{33}$ and less constrained by the realpolitik under which UNAIDS and other supranational organisations operate, these have sought to raise consciousness, mobilise community response and achieve change through, for example, sustained social media campaigns and education, high-profile events at international conferences, and research. Examples include the HIV Justice Network and HIV Justice Worldwide ${ }^{34}$, which have organised workshops and seminars alongside the International AIDS Conference for a number of years, maintain a database of law and cases, and provide regular commentary and analysis; the SERO Project ${ }^{35}$, which has promoted the HIV is Not a Crime message at training camps and in videos; and the Global Network of People living with HIV $(G N P+)^{36}$, which produced the Global Criminalisation Scan ${ }^{37}$.

A third contribution has been that of scholars, from a variety of disciplines including law and human rights, sociology and social psychology, and social policy, and practitioner-academics in law, public health, clinical medicine, virology and epidemiology. Through original empirical research outputs, expert analysis, commentary and critique, and films and documentaries, and often contributing to the work of civil society and international organisations, this diverse group has provided, and continues to provide, much of the intellectual argument, and evidence base, for decriminalisation, and their outputs form much of the supporting material in the various high-level reports and recommendations of UNAIDS and of the Global Commission on HIV and the Law.

If these are the some of the forms, techniques, and people that have been concerned with combating criminalisation (and no doubt there are more, and other ways of characterising and organising them), what success have they had? In the absence of any robust research, it is impossible to state with any degree of confidence what kind of intervention has made the most difference and why. Certainly, criminalisation persists globally, with cases being brought under laws

\footnotetext{
27 <https://www.nat.org.uk/nat-topic/criminalisation>

${ }^{28}$ National AIDS Trust Investigation Guidance relating to the Criminal Investigation of HIV Transmission for Police Forces in England, Wales, and Northern Ireland (2010) London: NAT < https://www.nat.org.uk/sites/default/files/publications/ACPO-guidance-criminal-HIV-transmission.pdf> ${ }^{29}$ Crown Prosecution Service for England and Wales Intentional or Reckless Sexual Transmission of Infection London: CPS < https://www.cps.gov.uk/legal-guidance/intentional-or-reckless-sexual-transmission-infection> ${ }^{30}$ Inter-Parliamentary Union, UNAIDS, UNDP Handbook for Parliamentarians No. 15: Taking Action Against HIV (2007) Ch 13 Geneva and New York: I-PU, UNAIDS, UNDP <http://data.unaids.org/pub/manual/2007/20071128_ipu_handbook_en.pdf>

${ }^{31}$ UNAIDS Judging the epidemic: A judicial handbook on HIV, rights and the law, Ch 5 (2013) Geneva: UNAIDS <http://www.unaids.org/sites/default/files/media_asset/201305_Judging-epidemic_en_0.pdf>

32 M Heywood 'South Africa's Treatment Action Campaign: Combining Law and Social Mobilisation in the Struggle for Health' (2009) 1 Journal of Human Rights Practice 14

${ }^{33} \mathrm{~J}$ Wright 'Only Your Calamity: The Beginnings of Activism by and for People With AIDS' (2013) American Journal of Public Health 103(10)1788; D Crimp 'Before Occupy: How AIDS Activists Seized Control of the FDA in 1988' (The Atlantic, December 6 2011) <https://www.theatlantic.com/health/archive/2011/12/before-occupyhow-aids-activists-seized-control-of-the-fda-in-1988/249302/> (Accessed 8 August 2018)

${ }^{34}<$ http://www.hivjustice.net>

$35<$ http://www.seroproject.com>

$36<$ https://www.gnpplus.net/who-we-are/about-us/>

37 <https://www.gnpplus.net/resources/2010-global-criminalisation-scan-report/>
} 
that have not been repealed, and new laws continually being introduced. ${ }^{38}$ There have, however, been successes, which it is reasonable to assume would not have been achieved, or achieved less quickly, but for this aggregate activity. Recent examples of progressive legislative change would include the decision of the Malawi Parliament in 2017 not to approve criminalisation provisions in the HIV (Prevention and Management) Bill ${ }^{39}$, and the repeal in 2015 of s19A of the Victorian Crimes Act, in Australia ${ }^{40}$, and in 2014 of lowa Code $\S 709 C .1^{41}$; and criminal prosecutions and convictions that have been abandoned or successfully appealed as the result of concerted and co-ordinated advocacy include the case of Michael Johnson in Missouri in 2016 ${ }^{42}$, and a ground-breaking decision of the Swedish Supreme Court in $2018^{43}$.

If any generalisation can be made about these victories for anti-criminalisation advocacy, it might be that it is the combination of research, activism, evidence-based argument, consciousness raising, and persistence that has been effective, with local / national targeted campaigns and projects (typically driven by activists and civil society organisations) drawing on the various supranational initiatives, reports and recommendations described above They are, however, exceptional. States, law enforcement agencies, and courts have been, and continue to be, slow to act - a legacy and effect of the time that to be HIV positive meant developing AIDS and dying, and of the discrediting stigma that continues to be associated with the disease ${ }^{44}$ despite radical advances in treatment ${ }^{45}$. And it is treatment that, arguably, has the potential to be a game-changer. The next section considers the impact of clinical developments and interventions as an innovative opportunity further

${ }^{38}$ Global Commission on HIV and the Law, Risks, Rights \& Health: Supplement pp 27-29 (2018) UNDP: New York < https://hivlawcommission.org> (Accessed 30 July 2018); EJ Bernard and S Cameron Advancing HIV Justice 2: Building momentum in global advocacy against HIV criminalisation (2016) Brighton and Amsterdam: HIV Justice Network and GNP+ <http://www.hivjustice.net/wpcontent/uploads/2016/05/AHJ2.final2_.10May2016.pdf> (Accessed 8 August 2018) ${ }^{39}<$ http://www.hivjustice.net/news/malawi-human-rights-activists-celebrate-malawis-adoption-of-amendedhiv-law-that-removes-rights-infringing-provisions-press-release/> (Accessed 8 August 2018)

${ }^{40}$ EJ Bernard and S Cameron Advancing HIV Justice 2: Building momentum in global advocacy against HIV criminalisation (2016) pp 37-38 Brighton and Amsterdam: HIV Justice Network and GNP+ <http://www.hivjustice.net/wp-content/uploads/2016/05/AHJ2.final2_.10May2016.pdf> (Accessed 8 August 2018)

${ }^{41}$ The lowa legislature, responding to the decision of the lowa Supreme Court in the case of Rhoades $v$ lowa (see above, Note 16), repealed its HIV criminalisation provision, which now provides, inter alia, that 'A person does not act with the intent required [...] or with the reckless disregard required [...] if the person takes practical means to prevent transmission, or if the person informs the uninfected person that the person has a contagious or infectious disease and offers to take practical means to prevent transmission but that offer is rejected by the uninfected person subsequently exposed to the infectious or contagious disease' <https://www.legis.iowa.gov/legislation/BillBook?ba=SF2297\&ga=85>. For a brief commentary on the legislation, and its shortcomings, see <https://www.hivlawandpolicy.org/news/statement-response-iowa-billsf-2297-and-criminalization-hiv-hepatitis-meningococcal-disease>

${ }^{42}$ B Guarino 'Man's conviction in failure to disclose HIV-positive status to sexual partners overturned by Mo. appeals court' Washington Post 21 December 2016 <https://www.washingtonpost.com/news/morning$\mathrm{mix} / \mathrm{wp} / 2016 / 12 / 21 / \mathrm{mans}$-conviction-for-failing-to-disclose-hiv-positive-status-to-sexual-partners-overturnedby-mo-appeals-court/?noredirect=on\&utm_term=.9b3e4dacefe2> (Accessed 10 August 2018)

${ }^{43}$ Högsta Domstolen (Swedish Supreme Court) Case Number B 2441-17 (June 7 2018). Judgment (in Swedish) available at <http://www.hogstadomstolen.se/Domstolar/hogstadomstolen/Avgoranden/2018/2018-0607\%20B\%202441-17\%20Dom.pdf> (Accessed 9 August 2018). The court accepted that people with HIV and who, like the appellant, have a well-functioning treatment and an undetectable viral load present no transmission risk. To convict a person of "causing danger to another person" there must have been an actual risk for HIV transmission.

${ }^{44} \mathrm{R}$ Parker and P Aggleton 'HIV and AIDS-related stigma and discrimination: a conceptual framework and implications for action' (2003) Social Science \& Medicine 57(1) 13

45 B Maughan-Brown 'Stigma rises despite antiretroviral roll-out: A longitudinal analysis in South Africa' (2010) Social Science \& Medicine 70(3) 368 
to limit criminalisation, their inter-relationship with the principles of criminal liability, and some of the unintended effects which they may have for those impacted by it

\section{THE IMPACT OF TREATMENT ON CRIMINALISATION}

It has long been established that the risk of onward HIV transmission is reduced significantly when a person living with HIV has a low viral load ${ }^{46}$, and a number of recent clinical studies show that those whose viral load is undetectable are not able to pass HIV on to other people. ${ }^{47} \mathrm{It}$ is also increasingly accepted that Pre-Exposure Prophylaxis (PrEP), where a person who does not have HIV takes antiretroviral drugs prior to engaging in sex with a person who does, is extremely effective in preventing its acquisition. ${ }^{48}$ The finding that effective anti-retroviral therapy (ART) can minimise, and in some cases eliminate, the risk of transmission and acquisition has been one of the most significant developments in HIV prevention in the past few years. It is the basis for the call by UNAIDS ${ }^{49}, \mathrm{WHO}^{50}$, and others representing PLHA and key populations for increasing the availability of, and accessibility to, treatment, and central to the ambition that, by $2020,90 \%$ of people living with HIV will know their status, $90 \%$ of those will receive sustained anti-retroviral therapy, and $90 \%$ of those will have viral suppression. ${ }^{51}$

The significance of ART's effectiveness for limiting the criminalisation of HIV transmission, exposure, and non-disclosure is self-evident: the fewer the number of new HIV infections, or potential new infections, there are, the fewer the cases there will, or at least should, be. It is, however, not quite that straightforward, for two main reasons. One has to do with the criminal law's approach to the evaluation and determination of harm and fault, the other with the fact that prevention and treatment access are not equally accessible and available to the people who need or would benefit from them.

46 TC Quinn, MJ Wawer, N Sewankambo, D Serwadda, C Li, F Wabwire-Mangen, et al, 'Viral load and heterosexual transmission of human immunodeficiency virus type 1. Rakai Project Study Group' (2000) N Engl J Med 342(13) 921; S Tovanabutra, V Robison, J Wongtrakul, S Sennum, V Suriyanon, D Kingkeow, et al, 'Male viral load and heterosexual transmission of HIV-1 subtype E in northern Thailand' (2002) J Acquir Immune Defic Syndr 29(3) 275; US Fideli, SA Allen, R Musonda, S Trask, BH Hahn, H Weiss, et al, 'Virologic and immunologic determinants of heterosexual transmission of human immunodeficiency virus type 1 in Africa' (2001) AIDS Res Hum Retroviruses 17(10) 901

${ }^{47}$ MS Cohen, YQ Chen, M McCauley, T Gamble, MC Hosseinipour, N Kumarasamy, et al, 'Prevention of HIV-1 infection with early antiretroviral therapy' N Engl J Med (2011) 11(365) 493; MS Cohen, YQ Chen, M McCauley, T Gamble, MC Hosseinipour, N Kumarasamy, et al, 'Antiretroviral therapy for the prevention of HIV-1 transmission' (2016) N Engl J Med 375(9) 830; Rodger, V Cambiano, T Bruun, et al, 'Sexual Activity Without Condoms and Risk of HIV Transmission in Serodifferent Couples When the HIV-Positive Partner Is Using Suppressive Antiretroviral Therapy' (2016) JAMA 316(2) 171.

${ }^{48}$ R Teira, F Vidal, P Muñoz-Sánchez, P Geijo, P Viciana, E Ribera, et al, 'Very low level viraemia and risk of virological faxilure in treated HIV-1-infected patients' (2017) HIV Med 18(3) 196; S McCormack, D Dunn, M Desai, D Dolling, M Gafos, R Gilson, et al, 'Pre-exposure prophylaxis to prevent the acquisition of HIV-1 infection (PROUD): effectiveness results from the pilot phase of a pragmatic open-label randomised trial' (2015) Lancet 387(10013) 53; RM Grant, T Liegler, P Defechereux, AD Kashuba, D Taylor, M AbdelMohsen, et al, 'Drug resistance and plasma viral RNA level after ineffective use of oral pre-exposure prophylaxis in women' (2015) AIDS 29331.

${ }^{49}$ UNAIDS HIV prevention 2020 road map: accelerating HIV prevention to reduce new infections by $75 \%$ Geneva: UNAIDS (2017) (https://hivpreventioncoalition.unaids.org/wp-content/uploads/2018/03/JC2909_ INCLUSION-GAP_013_En-2.pdf)

${ }^{50}$ World Health Organization Global Health Sector Strategy on HIV 2016-2021: Towards Ending AIDS (2016) Geneva: World Health Organization (http://www.who.int/hiv/strategy2016-2021/ghss-hiv/en/)

${ }^{51}$ UNAIDS 90-90-90: An ambitious treatment target to help end the AIDS epidemic (2014) Geneva: UNAIDS (http://www.unaids.org/sites/default/files/media_asset/90-90-90_en.pdf). 
The specific basis for criminalising HIV transmission, exposure, and non-disclosure depends on the law in the relevant jurisdiction. In England and Wales, for example, allegations of transmission are prosecuted under the Offences Against the Person Act 1861, there is no liability merely for exposing someone to the risk of infection (though there is if a deliberate attempt to transmit is proven ${ }^{52}$ ), and while there is no legal obligation to disclose HIV positive status, the failure to do so may result in a person proven to have transmitted the virus being denied the defence that the complainant consented to its acquisition (a defence which is otherwise available). In many other jurisdictions, exposure is sufficient to attract liability ${ }^{53}$, and in some, non-disclosure may render otherwise consensual sexual activity into sexual assault. ${ }^{54}$ These dimensions of liability are known as the conduct elements of the particular offences, and identify the harm concerned (e.g. causing an infection or posing a risk of infection).

As regards the mental, or fault, elements of liability, these too differ between jurisdictions but at the most general level a person proven to have committed the required conduct element will be guilty if it is established that they intended to transmit HIV, or were reckless as to whether or not transmission occurred. Intention in this context may mean a deliberate, purposeful, desire or some variation on transmission being virtually certain to occur and foreseen by the defendant as virtually certain; and reckless means a conscious awareness of taking an (objectively) unjustifiable risk (that transmission might occur).

The purely doctrinal aspects of the fault, and to a lesser degree ham, dimensions of HIV criminalisation are not the focus of this article and are explored in more detail and depth elsewhere. ${ }^{55} \mathrm{It}$ is, important, however, to make some preliminary observations before exploring their inter-relationship with developments in treatment. The first is that the meaning ascribed to terms such as 'risky' and 'harmful' in law do not map exactly on to the way they may be understood in medical and clinical discourse. Thus, in English law, the question of whether HIV constitutes 'grievous bodily harm' for the purposes of a charge under either section 18 and 20 of the Offences Against the Person Act 1861 will initially be a matter for the prosecuting authority and, ultimately a question for the jury to decide on the evidence; and the only guidance is that the term should bear the ordinary meaning of 'really serious' harm ${ }^{56}$, which in turn will be determined by applying contemporary social standards ${ }^{57}$. The fact that HIV was once an untreatable illness but is now often

\footnotetext{
52 Section 1, Criminal Attempts Act 1981

53 See UNAIDS Background Paper, Criminalisation of HIV Non-Disclosure, Exposure and Transmission: Background and Current Landscape (2011, 2012 Revised Version) Geneva: UNAIDS <http://www.unaids.org/sites/default/files/media_asset/JC2322_BackgroundCurrentLandscapeCriminalisation HIV_en.pdf> (Accessed 14 August 2018)

${ }^{54}$ See $R$ v Mabior, Note 3 above

55 See, for example, I Grant, 'The Boundaries of the Criminal Law: The Criminalization of the Non-Disclosure of HIV' (2008) 31 Dal LJ 123; M Weait 'Criminal Law and the Sexual Transmission of HIV: R v Dica' (2005) 68(1) Modern Law Review 121; M Weait 'Knowledge, autonomy and consent: R v Konzani', (2005) Criminal Law Review 763; D Hughes 'Did the Individual Consent to the Risk of Harm? A Comparative Jurisdictional Analysis of Consent in Cases of Sexual Transmission/Exposure to HIV' (2018) Journal of Criminal Law 82(1) 76; S Ryan, Risk-Taking, Recklessness and HIV Transmission: Accommodating the Reality of Sexual Transmission of HIV Within a Justifiable Approach to Criminal Liability' (2007) Liverpool Law Rev 28(2) 215; L Cherkassky, 'Being Informed: The Complexities of Knowledge, Deception and Consent when Transmitting HIV' (2010) The Journal of Criminal Law 24(3) 242

${ }^{56}$ DPP v Smith [1960] 3 WLR. 546

${ }^{57} R v$ Golding [2014] EWCA Crim 88. This was a case involving conviction under section 20 of the Offences Against the Person Act 1861 for the transmission of genital herpes. It was prosecuted as serious bodily harm despite the fact that in 2012 the WHO estimated the global prevalence of the virus which causes this (HSV-1)
} 
referred to by clinicians as a manageable chronic disease ${ }^{58}$ has not, to the author's knowledge, resulted in its being characterised in criminal law as anything other than serious ${ }^{59}$. This is the reason, for example, that in Canada non-disclosure of HIV status prior to engaging in conduct that has the potential to result in transmission (or is treated as having that potential) is charged as aggravated sexual assault (with the aggravation implying endangerment to life ${ }^{60}$ ).

More significant for the purposes of this article is the 'harm' of exposure (i.e. the unrealised risk of transmission), and its inter-relationship with the fault element of recklessness - a much more common form of mental state in reported criminal cases than intention. The core issue is this: should the criminal law treat risk taking as sufficiently culpable to warrant liability, censure and punishment whether the probability of it materialising is $5 \%$ or $95 \%$ ? If the harmful conduct is the taking of the risk (or, alternatively, the protection of an interest protected by the criminal law which the risk, if realised, would infringe) the likelihood of its realisation is arguably unimportant and not the court's job to evaluate. Similarly, where recklessness requires the defendant in a criminal case to be consciously aware of taking an unjustifiable risk (as it does in English law, and, with some variation in many other jurisdictions), of what precisely should she be aware before it is legitimate to hold her liable?

Following Findlay Stark's analysis ${ }^{61}$, it is arguably absurd to treat any risk, however negligible, as prima facie wrongful, and the requirement to justify risk taking (in order to avoid liability) should only apply in cases involving significant risk. The difficulty with this, of course, is that the moment a condition of significance, is introduced the question arises as to what counts as significant or (as in the US Model Penal Code ${ }^{62}$ ) substantial. Stark argues persuasively that although this is not a question that English courts have engaged with in any great detail, let alone one to which they have provided a conclusive answer, it is important that significance or substantiality be treated as a necessary condition for recklessness liability; and objections based on the impossibility of determining the relevant probability threshold ${ }^{63}$ can be met by recognising that this might legitimately vary as between different kinds of risk, the consequences of taking them, and the interests that the law is seeking to protect. This, however, should not detract from the central point, which is that

\footnotetext{
to be in the region of $67 \%$. See, KJ Looker et al 'Global and regional estimates of prevalent and incident herpes simplex virus type 1 infections in 2012' (2015) PLoS One 10(10) e014076

${ }^{58}$ SG Deeks, SR Lewin, DV Havlir 'The End of AIDS: HIV Infection as a Chronic Disease' (2013) Lancet 382(9903) 1525; S Serrano-Villar, F Gutiérrez, C Miralles et al 'Human Immunodeficiency Virus as a Chronic Disease: Evaluation and Management of Nonacquired Immune Deficiency Syndrome-Defining Conditions' (2016) Open Forum Infectious Diseases 3(2) ofw097e

${ }^{59}$ In the early years of the epidemic, and up until relatively recently, prosecutors did not shy from treating transmission as manslaughter or attempted murder. See, generally, KM Sullivan and MA Field 'AIDS and the Coercive Power of the State' (1988) 23 Harvard Civil Rights-Civil Liberties Law Review 139

${ }^{60}$ Section 273(1) Criminal Code (RSC 1985, c. C-46)

${ }^{61}$ F Stark Culpable Carelessness: Recklessness and Negligence in the Criminal Law (2016) Cambridge: Cambridge University Press

62 'A person acts recklessly with respect to a material element of an offense when he consciously disregards a substantial and unjustifiable risk that the material element exists or will result from his conduct. The risk must be of such a nature and degree that, considering the nature and purpose of the actor's conduct and the circumstances known to him, its disregard involves a gross deviation from the standard of conduct that a lawabiding person would observe in the actor's situation.' US Model Penal Code 2.02(c)

${ }^{63}$ L Alexander and KK Ferzan with S Morse Crime and Culpability: A Theory of Criminal Law (2009) Cambridge: Cambridge University Press
} 
The criminal law should not be, even in principle, capable of deployment in relation to trivial instances of risk-taking, even if the threatened outcome is harm to an interest protected by the criminal law. ${ }^{64}$

If we adopt, as I think we should, this principled approach to the criminalisation of HIV, it becomes clear that imposing liability on a person living with HIV where the risk of transmission is low (even where that person is aware of that risk) is at the very least problematic, and, arguably unjustifiable; and objective evidence about the probability of transmission, and expert consensus as to the meaning of that evidence, assumes vital importance. It is for this reason that recent interventions from the clinical and HIV research community are so important, and why both their value and limitations merit consideration.

\section{LIMITING CRIMINALISATION AND EXPERT EVIDENCE}

Expert scientific evidence has long played an important role in cases involving HIV transmission and exposure. In cases of alleged transmission, establishing that the defendant was the source of the complainant's infection has involved the presentation of phylogenetic analysis. ${ }^{65}$ This technique, which compares the strain of HIV in each of the parties, may (along with other narrative evidence, and the use of a control sample) support the contention that the defendant infected the complainant, but does not (and cannot) determine the source, route, or timing of transmission. Conversely, and importantly, it can provide definitive proof that the defendant was not the source of infection. ${ }^{66}$ As regards exposure liability, and cases where there is dispute as to whether the defendant was reckless as to the possibility of transmission ${ }^{67}$, the role of expert evidence is somewhat more complex. This is because the question of whether there was in fact a risk of infection of which the defendant could be aware at the relevant time, demands (or, arguably, should demand) inquiry into the probability of transmission. And this, in turn, requires investigators, prosecuting authorities, and courts to evaluate the reliability, significance, and - critically evidential relevance of research data and modelling studies on the likelihood of transmission on the facts of the specific case before them.

\footnotetext{
${ }^{64}$ F Stark Culpable Carelessness: Recklessness and Negligence in the Criminal Law (2016) Cambridge: Cambridge University Press, 16

${ }^{65}$ CJ Birch, RF McCaw, DM Bulach et al 'Molecular Analysis of Human Immunodeficiency Virus Strains Associated with a Case of Criminal Transmission of the Virus' (2000) The Journal of Infectious Diseases 182(3) 941; P Lemey, S Van Dooren, $\mathrm{K}$ Van Laethem et al 'Molecular testing of multiple HIV-1 transmissions in a criminal case' (2005) AIDS 9(15) 649; AB Abecasis, M Pingarilho, A-M Vandamme 'Phylogenetic analysis as a forensic tool in HIV transmission investigations' (2018) AIDS. 32(5) 543

${ }^{66}$ EJ Bernard, Y Azad, A-M Vandamme et al 'HIV forensics: pitfalls and acceptable standards in the use of phylogenetic analysis as evidence in criminal investigations of HIV transmission' (2007) HIV Medicine 8(6) 382; AB Abecasis, AM Geretti, J Albert et al 'Science in court: the myth of HIV fingerprinting' (2011) Lancet Infectious Diseases 11(2) 78

67 See, for example, Zaburoni v The Queen [2016] HCA 12 (6 April 2016), where the High Court of Australia had to determine, inter alia, consider whether the frequency of sexual intercourse between the appellant and the complainant, combined with his knowledge of his HIV positive status, his viral load, and how HIV is transmitted, justified the trial court's conclusion that he was guilty of transmitting a serious disease with intent or was more properly reckless as to that consequence. The Court noted, at para. 31, that among the agreed facts was the following: 'On the basis that the relationship between the complainant and the appellant lasted for a period of 21 months, the expert estimated there was approximately a 14 per cent risk of the appellant transmitting HIV to the complainant. This estimate was made without knowledge of the frequency of sexual intercourse or the possible presence of other factors which may increase the risk substantially.' It further noted (para. 32) that 'There was no evidence of what the appellant's viral load was in 2007 and 2008. There was no evidence that the appellant was aware of the statistical likelihood of the transmission of HIV as the result of unprotected penile-vaginal intercourse.'
} 
The first expert contribution addressing this was a controversial one. Between 1990 and 2009 there had been an estimated 39 convictions for alleged HIV exposure and transmission in Switzerland. For a relatively small country this was a high number. ${ }^{68}$ Of particular concern were prosecutions of PLHA under the Swiss Penal Code for "attempt at propagation of a dangerous disease" ${ }^{19}$ where the defendants were on effective treatment, and there was no transmission (the consent of the partner in such cases being no defence). ${ }^{70}$ Partly in response to this, the Swiss National AIDS Commission published a Report asserting that people with an undetectable viral load, and no subsisting STI, could not transmit HIV to their sexual partners. The controversy arose from the denial of the possibility of transmission despite the absence of robust evidence:

[The Commission] acknowledges that from a strictly scientific perspective, current medical and biologic data do not prove that effective antiretroviral therapy prevents all HIV infection, because it is not possible to prove the non-occurrence of an event that is certainly improbable, but theoretically possible. However, from the point of view of [the Commission] and the organizations concerned, the information available to date is enough to justify this message. [...] The situation is analogous to 1986, when the statement 'HIV cannot be transmitted by kissing' was publicised. While this finding has never been proven, more than twenty years of HIV experience has nevertheless helped to substantiate its strong plausibility. ${ }^{71}$ (Author's translation of French original)

The lead author of the Report subsequently indicated his regret at the categoric nature of the claim $^{72}$ (given the possibility of a residual risk), though subsequent research has confirmed the claim. ${ }^{73}$ More importantly, for present purposes, the Report was ground-breaking in being the first of a number of statements authored by highly respected experts in HIV medicine, immunology, and virology that have sought to draw attention to the impact of effective treatment on transmission risk, and impact on, the (mis) use of criminal law against PLHA.

These statements differ in their emphasis and intent. One, published in 2014 by Jan Albert and colleagues in Sweden, does not explicitly address the question of criminal liability, but provides a review of the research available at that time, concluding that, in the context of vaginal and anal intercourse

\footnotetext{
${ }^{68} \mathrm{~K}$ Pärli K and PM Payot Strafrechtlicher Umgang bei HIV/Aids in der Schweiz im Lichte der Anliegen der HIV/Aids-Prävention: Status quo, Reflexion, Folgerungen (2009) Bern: Swiss National Science Foundation <http://www.hivlaw.ch/strafbarkeit-der-hiv-uebertragung/studie/AJP1.pdf> (in German) (Accessed 18 August 2018)

${ }^{69}$ Swiss Penal Code Article 231, available in English at <https://www.admin.ch/opc/en/classifiedcompilation/19370083/201803010000/311.0.pdf> (Accessed 18 Aug 2018)

${ }^{70} \mathrm{R}$ Gasquez 'Pour la dépénalisation de l'exposition au VIH' (2009) 4/09 Plaidoyer

<http://www.groupesida.ch/media/documents/Plaidoyer_GroupeSidaGeneve_aout09.pdf>, available in English (unofficial translation) at <https://www.admin.ch/opc/en/classified-compilation/19370083/201803010000/311.0.pdf>

${ }^{71}$ P Vernazza, B Hirschel, E Bernasconi and M Flepp 'Les personnes séropositives ne souffrant d'aucune autre MST et suivant un traitment antirétroviral efficace ne transmettent pas le VIH par voie sexuelle' (2008) Bulletin des médecins suisses 89(5) 165

72 AIDSMAP 'The Swiss Statement and its repercussions' <http://www.aidsmap.com/The-Swiss-Statement-andits-repercussions/page/1746478/> (Accessed 20 August 2018)

${ }^{73} \mathrm{See}$, in particular, MS Cohen, YQ Chen, M McCauley et al for the HPTN 052 Study Team 'Prevention of HIV-1 infection with early antiretroviral therapy' (2011) NEJM 365 493; AJ Rodger, V Cambiano, T Bruun et al 'Sexual Activity Without Condoms and Risk of HIV Transmission in Serodifferent Couples When the HIV-Positive Partner Is Using Suppressive Antiretroviral Therapy' (2016) JAMA 316(2) 171
} 
- There is minimal risk of transmission through vaginal and anal intercourse if the HIVinfected partner is on effective ART and a condom is used throughout intercourse.

- There is also a very low risk of transmission through vaginal and anal intercourse if the HIV-infected partner is on effective ART and a condom is not used.

- The above applies for each individual sexual contact and in cases of repeated contact over the course of longer periods [...], regardless of whether the HIV-infected partner is a woman or a man and regardless of whether the HIV-infected partner is penetrative or receptive during the sexual act. ${ }^{74}$

Although this statement was not referred to directly in the 2018 Swedish Supreme Court case that overturned an exposure conviction, the Court did receive expert evidence from one of the authors (Anders Tegnell, of the Swedish Public Health Agency), and held that:

Scientifically, it will never be possible to prove that transmission of infection is impossible, but the conclusion that can be drawn is that it is so close to a non-existent risk of transmission of infection as it can be. With a different formulation, the risk of transmission of infection can be stated as non-observable. ${ }^{75}$ (Google Translate)

Two other, nationally focused, statements have been more explicit in their intent to inform decisions about the (mis)use of criminal law in their jurisdictions. Also published in 2014, Mona Loutfy and others from Canada declare in the introduction to their statement that

As leading Canadian HIV physicians and medical researchers, we have a professional and ethical responsibility to inform policy formulation and the criminal justice system in matters related to the health and well-being of our patients and Canadian society. We developed the present statement out of a concern that the criminal law is being used in an overly broad fashion against people living with HIV in Canada because of, in part, a poor appreciation of the scientific understanding of HIV and its transmission. We are concerned that actors in the criminal justice system have not always correctly interpreted the medical and scientific evidence regarding the possibility of HIV transmission, and may not have understood that HIV infection is a chronic manageable condition. This may lead to miscarriages of justice. ${ }^{76}$

And in 2016, an Australian expert statement was published which, concerned with ensuring 'just outcomes' in criminal cases concludes

Given the limited per act likelihood of HIV transmission during sex and the limited medical harms experienced by most people recently diagnosed with HIV, we

\footnotetext{
74 J Albert, T Berglund, M Gisslén et al 'Risk of HIV transmission from patients on antiretroviral therapy: A position statement from the Public Health Agency of Sweden and the Swedish Reference Group for Antiviral Therapy' (2014) Scandinavian Journal of Infectious Diseases 46(10) 673, 675

75 Högsta Domstolen (Swedish Supreme Court) Case Number B 2441-17 (June 7 2018) para 23. Judgment (in Swedish) available at <http://www.hogstadomstolen.se/Domstolar/hogstadomstolen/Avgoranden/2018/2018-0607\%20B\%202441-17\%20Dom.pdf> (Accessed 9 August 2018). The relevant passage in Swedish reads 'Vetenskapligt kommer det aldrig att kunna bevisas att överföring av smitta är omöjlig, men den slutsats som kan dras är att det är fråga om så nära en icke existerande risk för smittoöverföring som det går att komma. Med en annan formulering kan risken för överföring av smitta anges som icke beaktansvärd.'

${ }^{76}$ M Loutfy, M Tyndall, J-G Baril et al 'Canadian consensus statement on HIV and its transmission in the context of criminal law' (2014) The Canadian Journal of Infectious Diseases \& Medical Microbiology 25(3) 135, 135
} 
recommend that caution be exercised when considering criminal prosecutions, with careful appraisal of current scientific evidence on HIV risk and harms. ${ }^{77}$

Each of these statements draws on the most reliable scientific data, and seeks to draw attention to the per act risk with which criminal courts will typically be concerned, distinguishing between low, negligible, and no possibility (in contradistinction to the public health context characterization of sexual activity as ranging from high to low risk); and they provided the impetus for the most significant intervention of this kind, published at the World AIDS Conference in Amsterdam in 2018.

The Expert consensus statement on the science of HIV in the context of criminal law ${ }^{78}$, co-authored by many of the world's leading HIV experts (including Françoise Barré-Sinoussi, the Nobel Prize winning scientist who first identified HIV) is the most comprehensive and (potentially) influential contribution of the research and clinical community to the decriminalisation project. Building on earlier national statements, it too focuses on per act, or per event, absolute risk in the context of sex, biting, and spitting (the activities most frequently encountered in criminal cases), and draws attention to the fact that HIV infection is now a serious, but manageable, chronic condition. Importantly, it draws attention to what the authors view as a misuse of scientific data in cases such as $R \cup$ Mabior $^{79}$, which have relied on the relative risk approach deployed in public health discourse. As they explain, one error that legal authorities have made when estimating the transmission risk associated with particular acts has been to apply aggregate risk calculations to the conduct and activity of individuals on particular occasions. Thus, research which uses data suggesting that condoms are $80 \%$ effective against HIV transmission during penetrative vaginal sex could be interpreted to mean that on any one occasion there is a 1 in 5 chance that the receptive partner will be infected. This might result lead a court considering an HIV exposure allegation to determine the risk to be relatively high, and so result in conviction. However, as the Statement explains, 'if the estimated risk of HIV transmission from an HIV-positive man to a woman during a single episode of condomless vaginal sex is $0.08 \%$, then the risk of transmission when a condom is used can be understood as at least $80 \%$ lower, or $0.016 \%$ (less than 2 in 10,000). Furthermore, 'when other risk reduction factors are present (e.g. low viral load or withdrawal before ejaculation) the possibility of HIV transmission, even in the event of incorrect condom use, is further reduced's0 [References omitted].

The impact of this, other such statements, and the underpinning biomedical research on limiting prosecutions and convictions in transmission and exposure cases cannot be predicted. ${ }^{81}$ This will depend on the extent to which they are brought to the attention of investigating and judicial authorities, whether and how prosecution and defence lawyers use them, and the receptiveness of

77 M Boyd, D Cooper, EA Crock et al 'Sexual transmission of HIV and the law: an Australian medical consensus statement' (2016) Med J Aust 205(9) 409.

${ }^{78}$ Françoise Barré-Sinoussi, SSA Karim, J Albert et al 'Expert consensus statement on the science of HIV in the context of criminal law' (2018) Journal of the International AIDS Society 21 e2516 1

<https://onlinelibrary.wiley.com/doi/epdf/10.1002/jia2.25161> (Accessed 20 August 2018)

${ }^{79} R$ v Mabior (2012) SCC 47

${ }^{80}$ Françoise Barré-Sinoussi, SSA Karim, J Albert et al 'Expert consensus statement on the science of HIV in the context of criminal law' (2018) Journal of the International AIDS Society 21 1, 3-4

$<$ https://onlinelibrary.wiley.com/doi/epdf/10.1002/jia2.25161> (Accessed 20 August 2018)

81 It is important to note that the Expert Consensus Statement was published before the publication of the final Report of the PARTNER 2 study, which concluded 'that the risk of HIV transmission in gay couples through condomless sex when HIV viral load is suppressed is effectively zero': AJ Rodger, V Cambiano, T Bruun et al 'Risk of HIV transmission through condomless sex in serodifferent gay couples with the HIV-positive partner taking suppressive antiretroviral therapy (PARTNER): final results of a multicentre, prospective, observational study' Lancet (2019) 393 (2428) 2428 <https://www.thelancet.com/journals/lancet/article/PIIS0140-

6736(19)30418-0/fulltext> (Accessed 2 September 2019) 
judges and juries to expert evidence which, in common law jurisdictions such as England and Wales, is evidence that even if relevant and admissible, may - but need not - be take into account when reaching verdicts. It is, however, the case that if such statements do have a limiting effect, this will be in part because of the now overwhelming evidence about the effectiveness of ART, and its ability to reduce the viral load of a person living with HIV to a level which renders transmission impossible. And while this is no doubt one of the most significant advances in efforts to reduce the spread of, and ultimately eliminate, HIV, it is important to acknowledge that reliance on treatment as a means of limiting criminalisation means that it is only those to whom treatment is available and accessible who will benefit from it. This is a particularly serious matter, given the fact that many of those most impacted by criminalisation are those from population groups who are not only disproportionately affected by HIV but, often, less able to access ART or (in some cases) to achieve viral suppression if they are.

We know, for example, that migrants in the EU bear a heavier HIV burden than those born there. A 2009 Report $^{82}$ by the European Centre for Disease Prevention and Control (ECDC) found that, although there was notable variation ${ }^{83}$, the proportion of migrants living with HIV was more than $40 \%$ in some Member States (between $20 \%$ and $40 \%$ in most Western European countries); and in 2016 the proportion of people living with HIV born outside the reporting EU / EEA country accounted for $37 \%$ of all newly diagnosed cases of HIV infection. ${ }^{84}$ Although the prevention and treatment of $\mathrm{HIV}$ is an established political priority ${ }^{85}$, and, as an aspect of the right to the highest attainable standard of health and wellbeing, a recognised legal obligation, migrants at risk of, or living with, HIV, are ill-served in many European countries. Among the EU 27, only 13 offer free HIV testing for all, 8 offer free HIV treatment to general migrants from outside the EU, 3 provide free treatment for undocumented non-EU migrants with exceptions, and only 1 (the UK) provides undocumented migrants with treatment without exception. ${ }^{86}$ If it is the case that migrants from outside the EU are both more likely to be living with HIV and less able to access prevention and treatment services, it is perhaps unsurprising that there is at least some evidence ${ }^{87}$ that they have borne a higher criminalisation burden than others; and in the absence of universal ART roll-out without discrimination, expert evidence on the effectiveness of treatment will be of little or no value.

\footnotetext{
${ }^{82}$ European Centre for Disease Prevention and Control, Migrant health: Epidemiology of HIV and AIDS in migrant communities and ethnic minorities in EU/EEA countries, (2009, 2010 Revised Edition) Stockholm, ECDC.

${ }^{83}$ This reflects, in part, the colonial heritage and the prevalence of HIV in the countries from which their immigrant population comes.

${ }^{84}$ European Centre for Disease Prevention and Control, The status of the HIV response in the European Union/European Economic Area, 2016 (2017) Stockholm, ECDC

${ }^{85}$ Commission of the European Communities, Communication from the Commission to the European Parliament, the Council, the European Economic and Social Committee and the Committee of the Regions: Combating HIV/AIDS in the European Union and neighbouring countries, 2009-2013, (2009) COM (2009) 569 Brussels, EC; European Centre for Disease Prevention and Control, Background and methods. Monitoring the implementation of the Dublin Declaration to fight HIV/AIDS in Europe and Central Asia, (2013) Stockholm, ECDC

${ }^{86}$ Barring the way to health: Legal and regulatory barriers which impede the HIV care continuum in Europe, <http://legalbarriers.peoplewithhiveurope.org/en>. In 2017, there were an estimated 618,780 non-EU migrants illegally present in Member States: <http://ec.europa.eu/eurostat/statisticsexplained/index.php/Statistics_on_enforcement_of_immigration_legislation\#NonEU_citizens_found_to_be_illegally_present> (Accessed 6 August 2018)

87 GNP+ Europe and Terrence Higgins Trust Criminalisation of HIV Transmission in Europe: A rapid scan of the laws and rates of prosecution for HIV transmission within signatory States of the European Convention of Human Rights (2005) GNP+ and THT: Amsterdam and London. Available at <http://www.sidastudi.org/resources/inmagic-img/dd1694.pdf> (Accessed 8 August 2018)
} 
The same problem arises for others who experience social marginalisation and / or criminalisation for other reasons, such as sex workers ${ }^{88}$, transgender people ${ }^{89}$, people who use drugs ${ }^{90}$, men who have sex with men $^{91}$, and those in prison and otherwise detained ${ }^{92}$. All such people who also live with HIV have been shown to find accessing HIV treatment services more difficult, and many experience discrimination when attempting to do so. ${ }^{93}$ There is also a growing body of evidence showing that, at least with respect to some of of these populations in some jurisdictions, HIV transmission and exposure criminalisation is experienced more intensively than for the general population ${ }^{94}$, and a recent research study which explicitly demonstrated how many women living with HIV in Canada would be unable to maintain the viral suppression necessary to avoid criminal liability, even if this were acknowledged as a legitimate defence. ${ }^{95}$

\footnotetext{
${ }^{88}$ E Mountain, S Mishra, P Vickerman et al 'Antiretroviral Therapy Uptake, Attrition, Adherence and Outcomes among HIV-Infected Female Sex Workers: A Systematic Review and Meta-Analysis' N Sluis-Cremer, ed. (2014) PLOS ONE 9(9) e105645; S Baral, C Beyrer, K Muessig, et al 'Burden of HIV among female sex workers in lowincome and middle-income countries: a systematic review and meta-analysis' (2012) Lancet Infect Dis 12 538; K Shannon, JS Montaner 'The politics and policies of HIV prevention in sex work' (2012) Lancet Infect Dis 12 500; F Scorgie, D Nakato, E Harper, et al 'We are despised in the hospitals': sex workers' experiences of accessing health care in four African countries' (2013) Cult Health Sex 15 450Global Network of Sex Work Projects Global Briefing Paper: Sex workers' access to HIV treatment around the world (ND) Edinburgh: NSWP <http://www.nswp.org/sites/nswp.org/files/Global\%20Briefing\%20\%20Access\%20to\%20HIV\%20Treatment\%2 0-\%20English.pdf> (Accessed 8 August 2018)

${ }^{89}$ CJ Reback, K Clark, IW Holloway, JB Fletcher 'Health Disparities, Risk Behaviors and Healthcare Utilization Among Transgender Women in Los Angeles County: A Comparison from 1998-1999 to 2015-2016' (2018) AIDS Behav 22(8) 2524; AI Scheim, G-M Santos, S Arreola et al 'Inequities in access to HIV prevention services for transgender men: results of a global survey of men who have sex with men' (2016) Journal of the International AIDS Society 19(3) (Suppl 2) 20779

${ }^{90}$ A Sarang, T Rhodes and N Sheon 'Systemic barriers accessing HIV treatment among people who inject drugs in Russia: a qualitative study' (2013) Health Policy and Planning 28(7) 681; K DeBeck, T Cheng, JS Montaner et al 'HIV and the Criminalization of Drug Use Among People who Inject Drugs: A Systematic Review' (2017) The Lancet HIV 4(8) e357-e374

${ }^{91} \mathrm{G}$ Ayala and G M Santos 'Will the global HIV response fail gay and bisexual men and other men who have sex with men?' (2016) $19 \mathrm{~J}$ Int AIDS Soc 21098; International Lesbian Gay Bisexual Trans and Intersex Association (ILGA) State-sponsored Homophobia: A world survey of sexual orientation laws: Criminalisation, protection and recognition (2017) <https://ilga.org/state-sponsored-homophobia-report> (Accessed 8 August 2018)

92 R Jürgens et al 'HIV and Incarceration: prisons and detention' (2011) $14 \mathrm{~J}$ Int AIDS Soc 26; F L Altice et al 'The perfect storm: incarceration and the high-risk environment perpetuating transmission of HIV, hepatitis C virus, and tuberculosis in Eastern Europe and Central Asia' (2016) 388 The Lancet 1228

${ }^{93}$ ECDC Evidence brief: Impact of stigma and discrimination on access to HIV services in Europe (2017) Stockholm: ECDC <https://ecdc.europa.eu/sites/portal/files/documents/Dublin-EB-

Stigma\%20and\%20discrimination\%202017_final.pdf> (Accessed 8 August 2018); AJ Hakim, V MacDonald, W Hladik et al 'Gaps and opportunities: measuring the key population cascade through surveys and services to guide the HIV response' (2018) Journal of the International AIDS Society 21(Suppl 5) e25119

${ }^{94}$ The Williams Institute at UCLA is undertaking some of the most innovative and important work in this area. See, for example, A Hasenbush HIV Criminalization in Georgia: Penal implications for people living with HIV/AIDS (2018) Los Angeles: The Williams Institute / UCLA School of Law <https://williamsinstitute.law.ucla.edu/wp-content/uploads/HIV-Criminalization-Georgia-Jan-2018-1.pdf>; A Hasenbush, B Wilson, A Miyashita and M Sharp HIV Criminalization and Sex Work in California (2017) LoS Angeles: The Williams Institute / UCLA School of Law <https://williamsinstitute.law.ucla.edu/wpcontent/uploads/HIV-Criminalization-Sex-Work-Oct-2017.pdf> (Accessed 8 August 2018)

${ }^{95}$ A Krüsi, K Deering, F Ranville et al for the SHAWNA Project Team 'Marginalized women living with HIV at increased risk of viral load suppression failure: Implications for prosecutorial guidelines regarding criminalization of HIV non-disclosure in Canada and globally' Oral Abstract presented at AIDS2018< http://programme.aids2018.org/Abstract/Print/?abstractid=11316> (Accessed 20 August 2018)
} 
The fundamental problem is, arguably, that reliance on biomedical advances in HIV treatment as a limiting strategy in the decriminalisation project will enable some at risk of prosecution and conviction to minimise this, while for others it may do no such thing - serving to sustain and reinforce the divide in legal protections between those who for whom ART is available and accessible and those in key populations for whom it is not, or for whom adherence is rendered complex through socio-economic factors beyond their immediate control. A number of scholars have raised questions about the impact of what they see as a biomedical (as distinct from social and behavioural) focus in the HIV response, suggesting, among other things, that it is unhelpfully reductive and fails to recognise the diverse experience of PLHA. As Persson puts it, referring to the Treatment as Prevention paradigm

With its seemingly simple solution and global generalisability, it promises to cut through or circumvent the messy intricacies of people's lives and sexual relationships and usher in an era of normalisation [...]. But it is a promise premised on the assumption of a comprehensive transition from one coherent HIV corporeality to another, no matter cultural and individual specificities. The liberal rationality that underpins this paradigm, and HIV prevention more broadly, is problematic because [...] experience is a contentious, incomplete, emergent process, and thus human intentions rarely produce what is intended. ${ }^{96}$

Similar points may be made in the present context, and we should perhaps be at the very least sceptical about the potential for expert evidence that relies on the preventive power of treatment to limit criminalisation for those it most typically impacts, unless this is accompanied by the arguments grounded in the principles of justice, fairness and rights advanced by activists and others, and considered earlier in this article.

\section{CONCLUDING OBSERVATIONS: A PRINCIPLED LIMIT TO DECRIMINALISATION?}

The HIV criminalisation cases that are typically the focus of concern to those advocating for reform, have been those where PLHA have been prosecuted in the absence of any intention to do harm to others and where HIV was not (and in many cases could not) have been transmitted. These comprise the bulk of cases that are investigated, prosecuted, and come before the courts worldwide, and have been the ones to inform the recommendations of UNAIDS and the Global Commission on HIV and the Law - which, put summarily, are that while intentional transmission (and intentional attempts to transmit) may justify state punishment, the adverse public health impact and unfairness associated with conduct less serious than this mean that such conduct should not be criminalised. ${ }^{97}$ What, though, of the rare case that falls within the exception: the person who is proven to have intended

\footnotetext{
${ }^{96}$ A Persson 'Non/infectious corporealities: tensions in the biomedical era of 'HIV normalisation' (2013) Sociology of Health \& Illness 35(7) 1065, 1076. See also, P Flowers 'HIV transitions: Consequences for self in an era of medicalisation' (2010) in M Davis and C Squire (eds) HIV Treatment and Prevention Technologies in International Perspective Basingstoke: Palgrave Macmillan; M Rosengarten HIV Interventions: Biomedicine and the Traffic between Information and Flesh (2009) Seattle, WA: University of Washington Press; S Kippax and N Stephenson 'Beyond the distinction between biomedical and social dimensions of HIV prevention through the lens of a social public health' (2012) Journal of Public Health 102(5) 789
}

97 Global Commission on HIV and the Law, Risks, Rights \& Health (2012) Recommendations 2.1-2.4 UNDP: New York < https://hivlawcommission.org> (accessed 30 July 2018) 
to harm another, or to have purposefully sought to harm another, through the agency of HIV? Is this the limit case? Should such a person necessarily be criminalised?

In 2017 Daryll Rowe was tried in the Crown Court at Lewes for infecting five male partners with HIV, and trying unsuccessfully to infect a further five. There was evidence that he had sabotaged condoms, lied about his HIV status, and sent aggressive, taunting, emails after having had unprotected sex in which he disclosed his positive status. He was was convicted on all ten counts of causing, and of attempting to cause, grievous bodily harm, and in April 2018 he was sentenced to life imprisonment with a minimum term of 12 years. ${ }^{98} \mathrm{He}$ was also sentenced, in respect of four offences committed in Scotland and to which he admitted, to a concurrent 8 years imprisonment. ${ }^{99}$ This was the first case in the UK in which a person of someone being convicted of intentionally harming, or attempting to harm, others with HIV (all other convictions have been for reckless transmission).

On their face, the circumstances of Rowe's conviction satisfy international recommendations, and certainly his behaviour was found to have manifested a wanton disregard for his sexual partners. It is difficult to see how how one might, or wish to, suggest that liability on facts like those in Rowe's case is not warranted, even if one accepts the arguments for decriminalisation in principle. It is, however, important to recognise, that the legitimacy of a conviction in such a case, or indeed in any criminal case (other than for regulatory offences of strict liability), depends on satisfying two basic criteria. One of these is establishing that the moral fault of the defendant is of a sufficiently grave kind - in this case the desire to hurt, or to harm, the victim; and the second is that the means of achieving that harm, or hurt, is of a kind recognised and identified as a sufficiently serious violation of the victim's interests. ${ }^{100}$ Unless both of these criteria are met, criminal liability is not warranted.

What this means is that it is if, and only if, we accept as axiomatic that HIV is a serious harm that the criminalisation of HIV is justified; and that, as I have explored more fully elsewhere ${ }^{101}$, is a choice. We could choose, as a society, to identify people living with HIV as harmed people, in respect of whose infection it is merely a matter of context whether it provides the basis for a criminal charge (dependent in part on the intention of the person who infected them); or we could choose to characterise HIV as an environmental phenomenon, whose movement between people is as much a consequence of, for example, the resilience of mucosal membranes and the accessibility and availability of effective treatment. We could choose to recognise that, although the management of HIV infection means taking medication for the rest of one's life, so too do many other conditions that we live with, and we could choose to acknowledge that those whose HIV is diagnosed in a timely way and who start treatment live otherwise long and healthy lives ${ }^{102}$, and that such treatment has meant that the cause of of death of PLHA is increasingly from non-HIV-related causes rather

\footnotetext{
$98 \mathrm{~K}$ Rawlinson 'Man jailed for life after deliberately infecting men with HIV' The Guardian, 18 April $2018<$ $<$ https://www.theguardian.com/uk-news/2018/apr/18/hairdresser-daryll-rowe-given-life-sentence-fordeliberately-infecting-men-with-hiv> (Accessed 15 August 2018)

${ }^{99} \mathrm{~S} J$ Johnson 'Hairdresser Daryll Rowe sentenced in Scotland for trying to infect more men with HIV' The Telegraph, 4 May 2018 <https://www.telegraph.co.uk/news/2018/05/04/hairdresser-daryll-rowe-sentencedscotland-trying-infect-men/> (Accessed 15 August 2018)

$100 \mathrm{~J}$ Feinberg Harm to Others (1984) Oxford: Oxford University Press, 1984; M Moore, Placing Blame: A General Theory of the Criminal Law (1997) Oxford: Oxford University Press

${ }^{101}$ M Weait 'HIV and the meaning of harm' (2016) in C Stanton and H Quirk (eds) Criminalising Contagion: Legal and Ethical Challenges of Disease Transmission and the Criminal Law Cambridge: Cambridge University Press

${ }^{102} \mathrm{G}$ Wandeler, LF Johnson, and M Egger 'Trends in life expectancy of HIV-positive adults on antiretroviral therapy across the globe: comparisons with general population' (2016) Curr Opin HIV AIDS 11(5) 492
} 
than AIDS-defining illnesses. ${ }^{103}$ Or we could choose, as Denmark did in 2011, to review the application of the law and not to pursue HIV criminalisation. ${ }^{104}$

There is, however, little appetite for reform, and the Law Commission for England and Wales has recently recommended that the current legal position in this jurisdiction be retained (and that any change be subject to a wider review) ${ }^{105}$ More generally, it is of possible to acknowledge that the choices set out above may be made without necessarily concluding that they provide a sufficient rationale for comprehensive decriminalisation. Intentional transmission, such as that exemplified in Daryll Rowe's conviction, may indeed serve as the limit case - as the one which even the most fervent decriminalisation advocates find impossible to defend (or choose, for practical and political reasons, not to). If it does so serve, and if those advocates' ambitions do not extend to challenging the characterisation of HIV as a serious harm in the criminal law context, but merely to limiting liability (through, for example, deploying expert evidence about the effect of treatment), the battle will only, and can only, be partially won.

\footnotetext{
${ }^{103}$ SG Deeks and AN Phillips 'HIV infection, antiretroviral treatment, ageing, and non-AIDS related morbidity' (2009) BMJ 31(338) 288

${ }^{104}$ EJ Bernard 'Denmark: Justice Minister suspends HIV-specific criminal law, sets up working group' 17

February $2011<$ <ttp://www.hivjustice.net/news/denmark-justice-minister-suspends-hiv-specific-criminal-lawsets-up-working-group/> (Accessed 20 August 2018)

${ }^{105}$ Law Commission Reform of Offences Against the Person (Law Com 361) Ch 6 London: Law Commission
} 